UDK 658.562.012.7

L. Perperi, PhD, Assoc. Prof.,

H. Oborskyi, DSc, Prof.,

G. Goloborodko, PhD, Assoc. Prof.,

Yu. Palennyy

Odessa National Polytechnic University, 1 Shevchenko Ave., Odessa, Ukraine 65044; e-mail: 1mp.mvms@ukr.net

\title{
IMPROVING THE MODEL OF QUALITY MANAGEMENT SYSTEMS PROCESSES ASSESSMENT
}

\begin{abstract}
Л.М. Перпері, Г.О. Оборський, Г.М. Голобородько, Ю.Г. Паленний. Удосконалення моделі оцінки процесів системи управління якістю. Розглянуті питання, пов'язані з розробкою концепції удосконалення моделі оцінки якості процесів на підставі вимірювання досягнення запланованого рівня результативності із застосуванням «шкали зрілості». Визначені принципи, закладені в модель оцінки, які засновані на розумінні того, що процес оцінки не $\epsilon$ «лінійним» процесом, а $є$ процесом, який функціонує як безперервний цикл. Запропонована вдосконалена модель оцінки процесу із застосуванням принципів «структурної моделі» і реалізацією методології РDCА дозволяє забезпечити представлення можливостей процесів на рівні організації, забезпечуючи прозорість в поданні здатності процесів створювати цінності.

Ключові слова: управління якістю, модель оцінки, процес оцінки, рівень можливостей, властивості процесу, модель зрілості

L. Perperi, H. Oborskyi, G. Goloborodko, Yu. Palennyy. Improving the model of quality management systems processes assessment. Considered are the issues related to elaboration of processes quality assessment model improvement based onto the assessment of the expected result achievement level using the "maturity scale". Defined are that assessment model's principles departing from the concept of assessment process as not "linear" one but this one operating in so-kind a continued cycle. Suggested is the improved process assessment model applying the "structural model" principles that, implementing the PDCA methods, allows representing the processes' occurrence at the organizational level that provides the transparency of processes' ability to values creation representing.

Keywords: quality management, assessment model, assessment process, level of capabilities, process properties, maturity model
\end{abstract}

Introduction. The modern paradigm of quality management system at higher education institutions (HEI) consists in changing the management orientation from the top-down management model to the cyclic one of continuous improvement aimed at meeting the customers' and other stakeholders' requirements, needs and expectations. One of such methodologies embodies the organization's activities system management based on the application of process approach in accordance with the ISO 9001: 2015 requirements. When using the process approach for building the HEI quality management system, activities of subjects included in the organizational structure are considered as a set of interrelated processes. The HEI quality management system should be oriented towards managing both individual processes and their interrelations, and the internal quality assurance system [1] shall ensure these processes execution quality [2-4].

In accordance with ISO 9001: 2015 main provisions, in order to implement the process approach when quality management system building, first of all necessary is to identify the main, managerial and supporting processes, their interrelations and ways to manage them. When processes determining, it should be borne in mind that their main goal refers to achieving results planned in accordance with the given organization quality policy and development strategy. Continuous process improvement and quality management system is achieved by using the Plan-Do-Check-Act (PDCA) Shewhart-Deming cycle as the processes development basis. The process approach application is aimed at solving a number of problems, important place among which holds the task of reaching the processes' specified performance for their continuous improvement. Such development can be achieved using reliable and adequate information on the assessed processes. Therefore, a detailed consideration of the processes quality assessment issues embodies an urgent task.

Analysis of recent research and publications. The analysis of latest publications related to the quality management systems processes assessment showed that most of them are aimed at meeting the ISO 9001 standard requirements at the institutional level, including:

DOI: 10.15276/opu.1.54.2018.16

(C) 2018 The Authors. This is an open access article under the CC BY license (http://creativecommons.org/licenses/by/4.0/). 
- use of monitoring technique, demonstrating the processes' ability to achieve the planned results and, where possible, ensure the quality management system processes' dimensions evaluation;

- analysis of monitoring results to assess the quality management system suitability and effectiveness, identifying processes in which the quality management system effectiveness can be improved.

Thus, to determine the controlled process parameters, proposed is an analytical algorithm that takes into account the monitoring (measurement) level and method as well as the processes' outcomes [5].

In addition, it is indicated [6] that:

- to assess the quality management system each process effectiveness necessary is to use certain indicators, for which measurement the dimensionless scales are used;

- when processes assessment, it is necessary to consider which area of management processes activity they are related to: the main or auxiliary one.

The same source suggests using a general quality index for processes assessment. For this purpose, four groups of process quality indicators are identified by the optimality criterion. Dependencies are obtained for the evaluation of any quality management system process, taking into account the indicators of quality indicators weight and optimality.

Known is the qualimetric approach to the quality management system processes' assessment, described in [7]. A methodology for processes quality quantitative assessment is developed, using a system of dependencies between single different-scale assessed indicators with a dimensionless assessment scale using desirability functions.

Within the framework of researches listed, tasks related to various aspects of the organizations' quality management systems processes performance assessment have been solved, still there remains urgent the task to solve the problems of assessing processes' state in order to determine their improvement possibilities.

This research aim is to develop a concept for improving the process quality assessment model based on measuring the achievement of the planned performance level using criteria departing from the "maturity scale".

To achieve this goal, the following tasks are formulated:

- analysis of existing methodological approaches to assess the quality management system processes functioning level;

- development of the process assessment model improvement concept;

- description of the methodology for measuring the process assessment model capabilities.

Main research material statement. As a research method, the continuous improvement principle based on the process approach using the PDCA cycle, adopted in the standard ISO 9001: 2015 and the draft standard ISO / DIS 21001: 2017 "Educational organizations - Management systems for educational organizations. - Requirements with guidance for use" has been selected. In accordance with these standards recommendations, the organization having completed the "Plan" scheduled stage which requirements are specified in the standard's sections 4-7 and the "Do" activities stage by the products and services life cycle phases, which requirements are given in Section 8, it should proceed to the implementation of stages associated with "heck" activities' outcomes assessment, which requirements are given in Section 9, and the "Act" improvements specified in Section 10. Based on comparison between "Check-Act" steps, we can conclude, that the main focus is on planning and implementing processes, measuring, analyzing and evaluating the performance indicators of the organization's quality management system. In order to demonstrate the processes' capabilities to achieve the planned results, it is necessary to determine the appropriate methods and indicators for processes monitoring and measuring. In addition, in order to guarantee the obtained results' reliability and to determine the possibilities for a continuous improvement, it is necessary to define methods for process parameters analysis and assessment.

One of the ways to improve the organization's product and/or services quality is to use the method of its processes assessment applying results obtained for the continuous improvement program. The process assessment purpose is to determine the key organizational processes status, as well as to identify opportunities and ways to improve processes. 
In accordance with ISO / IEC 33001: 2016, processes are evaluated by comparing their outcomes with the quality objectives planned in the process assessment model. The location and relationships of the reference model and the assessed process indicators in the assessment model $[8,9]$ are shown in Fig. 1.

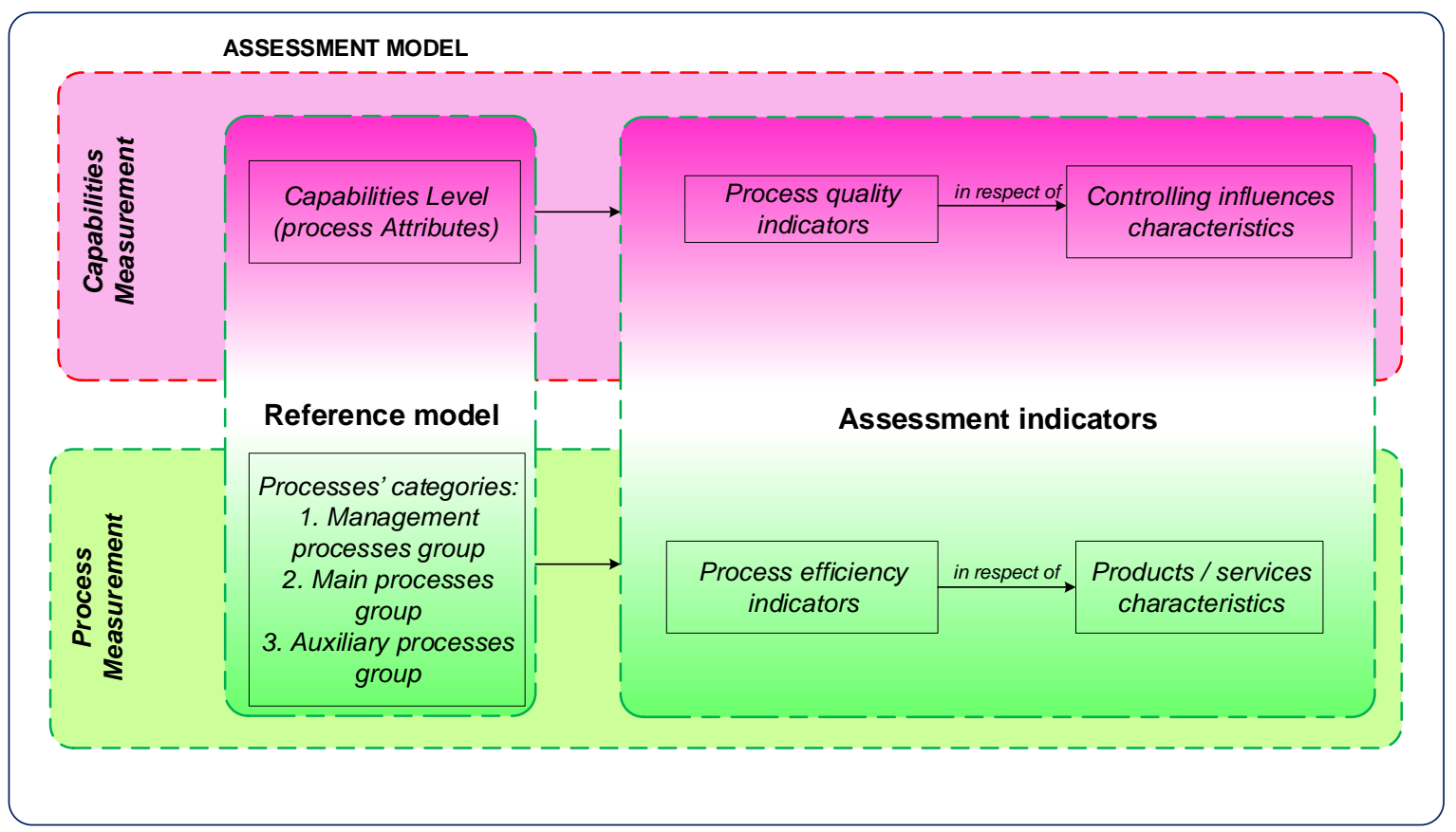

Fig. 1.Relation between the assessment model, processes' reference model and assessment indicators

The represented assessment model includes groups of the corresponding categories' processes containing processes' goals and outcomes and their assessment systems, bearing a set of attributes in relation to their qualitative characteristics. These attributes grouped in the capability levels are applied to all processes.

The processes' attributes should be understood as their objective characteristics, manifested in its implementation and management. The indicators of process quality are their quantitative normalized attributes' characteristics. Performance indicators here represent qualitative or quantitative characteristics in relation to the processes' outcomes characteristics.

At all process assessment stages, to ensure evaluation results' repetition and reliability, it is necessary to register documentarily the indicators compliance degree based on objective evidence.

To evaluate the processes at the Odessa National Polytechnic University (ONPU), proposed is an evaluation model that takes into account principles above and for which description the "structural model" principles are used. Speaking of processes structural model we imply a sequence, the work stages contents and arrangement, as well as the set of processes participants' interactions [9].

The process assessment model basic element is a reference model, which involves measuring both the results (processes outcomes) and the capabilities that characterize their properties during the PDCA cycle phases. The processes reference model is developed for various kinds of organization activity. In accordance with ISO 9001:2015 standard, process areas are divided into categories: management processes, main processes and auxiliary processes, which definitions are presented in the Table.

The reference process model is used as a pattern model for processes development, and also serves as a criterion for these processes assessment. In this case, the reference model is unified for all processes categories: managing, main or auxiliary, as this is shown in the organization's process landscape [10].

The proposed processes assessing model (Fig. 2) can be used by the top management of the organization for processes internal assessment (self-assessment). The process assessment objectives are 


\begin{tabular}{c|c}
\multicolumn{2}{c}{ Description of process categories } \\
\hline Process categories & Description \\
\hline Managing processes & $\begin{array}{c}\text { Set of various activities } \\
\text { aimed at coordinating the } \\
\text { organization's functioning } \\
\text { Activity result: management } \\
\text { resources delivered to other } \\
\text { processes' inputs }\end{array}$ \\
\hline Main processes & $\begin{array}{c}\text { Product / service life cycle } \\
\text { processes that add value for } \\
\text { customers satisfaction. } \\
\text { Activities result: product } \\
\text { release /service rendering }\end{array}$ \\
\hline Auxiliary processes & $\begin{array}{c}\text { Processes whose } \\
\text { performance is intended to } \\
\text { ensure the main processes' } \\
\text { functioning }\end{array}$ \\
\hline
\end{tabular}

determined in accordance with the assessment task objective and the assessment purpose. In order to ensure confidence in the assessment results accuracy and the $\mathrm{s}$ assessment scope, three levels of assessment are provided.

The first assessment level is used to compare the own enterprise main processes' activities outcomes with these of the competitors' activities in order to identify the strengths and weaknesses in relation to them.

The second assessment level is designed to compare the outcomes of key managing, main and auxiliary processes within the organization with the aim of identifying both ways to improve and risks, thereby providing the basis for making improvements in the process planning.

The third assessment level is used to obtain outcomes that can indicate possible areas of improvement and areas of risk for the assessed processes and serve as a basis for subsequent assessment levels: the second and the first one.

The assessment process activities at each level are implemented using the PDCA cycle. The result of "Do" stage activity at the first level will represent the managerial order for the second level assessment. The "Do" stage result at the second level of management will embody the approved plan of activity for the third level assessment process. The third level assessment is carried out in accordance with the approved activity plan for the process based on the reference process model, in accordance with the documented procedure and the information card of the process to be assessed. At this level "Plan" stage, the processes quality assessment (PQA) plan is prepared in accordance with the approved process activity plan by the leading appraiser of the Quality Assurance Center for Higher Education (QACHE) of the ONPU.

In the "Do" stage, the QASCHE process quality assessment team collects data for PQA and confirms those data, determines the PQA results in accordance with the approved PQA procedure, which consists of five steps:

1) determining the assessment scope;

2) identification of objective evidence for each process indicator and measurement system;

3) collection of objective evidence for each process indicator;

4) determining each process indicator assessment outcome compliance degree to the established criteria;

5) collection of additional information related to the assessment.

At this stage, the process quality assessors' team measures the effectiveness and capabilities of the processes according to their attributes' characteristics with respect to the control actions.

At the "Check" stage, the group of process quality evaluators performs an analysis of compliance with regulatory requirements specified in the reference process model. The evaluation is performed, comparing the obtained evaluation results subjective with the criteria established in the reference model.

At the "Act" stage the assessing group together with the process owner, develops a draft improvement plan. Further, the assessment results (assessment certificates, assessment report, draft improvement plan) are subjected to the conformity analysis of the assessment model by the process reference model, at the quality assessment second level implemented by the QACHE consultant. At the second assessment level, based on the analysis conducted by QACHE expert, an improvement plan is drawn up, and the assessment results are transferred to senior management for analysis and decisionmaking on improvements introduction to the organization's activities. 


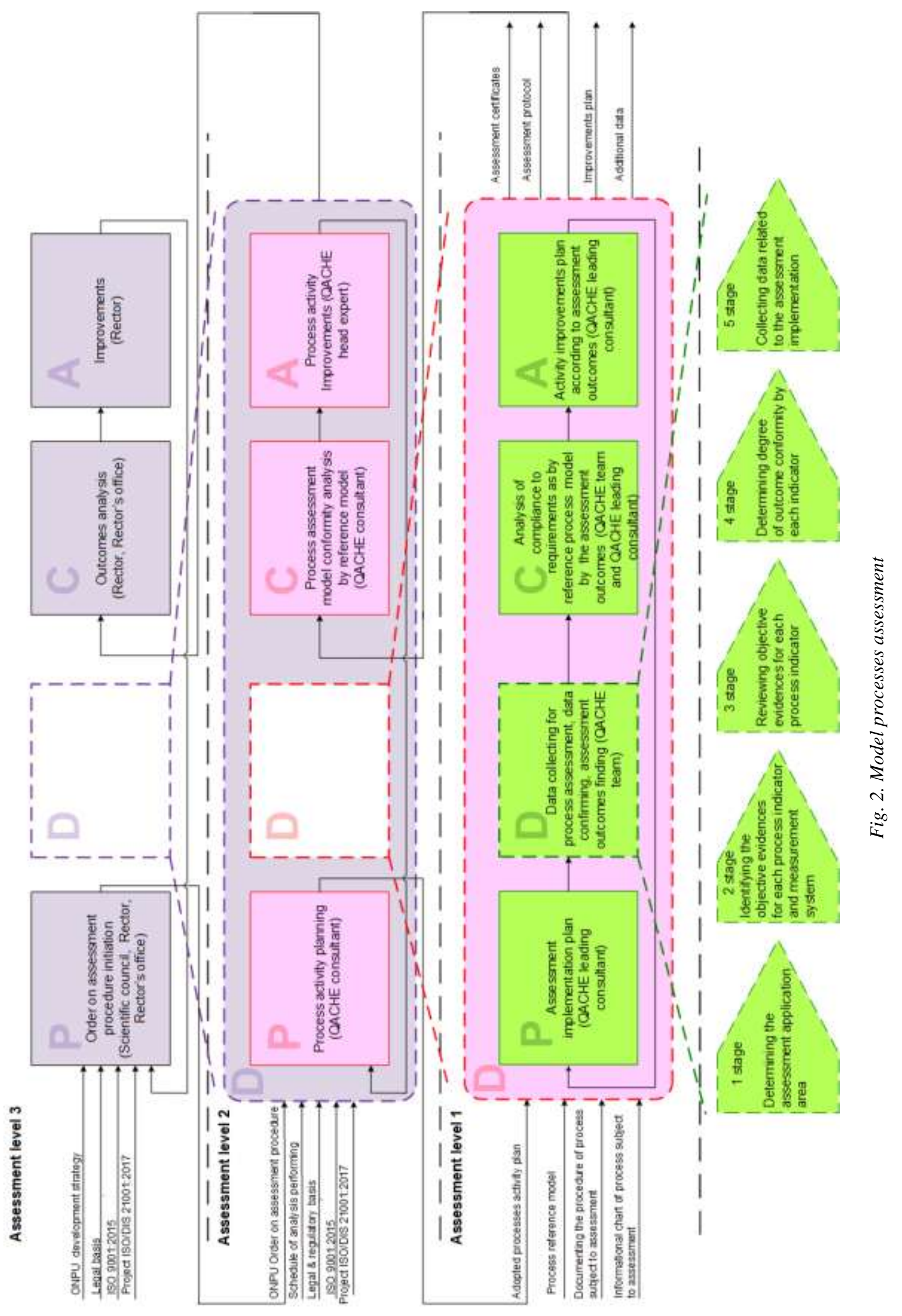


The assessment model is designed in such a way as to maximally meet the HEI's needs for process assessment, taking into account the educational services rendering specifics. The principles embodied in the described assessment model are based on the understanding that the assessment process is not "linear", but functions as a continuous cycle. Processes' assessment based on the proposed model contains two aspects of the measurement system.

The first aspect is connected with the formation of a judgment on implementation of actions sequence $\mathrm{n}$ accordance with the established process stages, in order to determine the extent to which the objectives have been achieved. The first aspect is called the processes measurement.

The second aspect is related to the definition of a set of control actions, aimed to provide a demonstration of the assessed process attributes achievement degree. The second aspect is called the processes capabilities measurement.

The processes measurement in the assessment model is determined by a set of sequential steps performed to achieve the process goal. These actions' set shows what exactly needs to be done to obtain the outcomes. Each product /service has its own characteristics, serving in basis to evaluate the process performance.

The measurement of process capabilities in assessment model involves the use of a set of properties defined in the ISO /IEC 33020:2016 standard. These properties tend to show the levels of the assessed processes capabilities. Process attributes are measured as a percentage of total achievement and represent characteristics for any process.

Each level of capability is characterized by a certain set of process attributes. The degree of their conformity in percent on a rating scale from 0 to 100 indicates the process capabilities level achievement.

Process improvement by its capabilities levels represents its development from the lack of organization activities, which corresponds to the absence of the process as such, to the controlled, measurable, reproducible one with predictable results. The top of the process improvement is the level of "selfoptimization" without external control action. In practice, each process is unique, with its attributes, and its development is continuous. However, for the convenience of processing information on the process improvement levels, development levels are conditionally divided into "maturity levels", which in the CMMI, CMM, and ISO 33000 assessment models are divided into 5 levels [11]. Thus, the obtained discrete maturity assessment scale makes it easier to select the point of forces application to make changes at the current management system to achieve greater results while reducing the cost of system changing.

As a result of the conducted studies, it was determined that in order to satisfy the requirements related to the measurement, analysis and assessment of the organization's quality management system performance indicators, it is necessary to determine:

- methods of measuring processes, ensuring the demonstration of their abilities to achieve the planned results;

- methods for assessing the processes' characteristics ensuring the reliability of outcomes and to determine the possibilities for their continuous improvement.

When solving tasks set for the development of a quality management system processes assessing model, this one for assessing the processes quality in information technology was used as a basis. The proposed improved assessment model using the "structural model" principles and implementing the PDCA methodology makes it possible to demonstrate the processes capabilities at the organization level, providing transparency in the representation of processes ability to create values.

Conclusions. The process capabilities levels identified during the quality assessment allow the senior management to plan for improving the quality system, based on facts. Assessing the capabilities level, expressed in numerical form, we can select mechanisms of process management, based on objective data obtained during the quantitative assessment. Process assessments, expressed in quantitative form, are easier to compare and, based on the assessment results, to determine goals, which achievement will result in the most significant outcomes. Further research will be devoted to the theory of measurements and system analysis. 


\section{Литература}

1. Про вищу освіту : Закон України від 01.07.2014 р № 1556-VII. Дата оновлення: 16.04.2017. URL: http://zakon2.rada.gov.ua/laws/show/1556-18/page (дата звернення: 25.01.2018)

2. Luís Fonseca, José Pedro Domingues. ISO 9001:2015 edition - management, quality and value. International Journal for Quality research. 2017. 11(1), P. 149-158. DOI: https//doi.org/10.18421/ IJQR11.01-09.

3. Goutam Kumar Kundu. Quality in higher education from different perspectives: a literature review. International Journal for Quality research. 2017. 11(1), P. 17-34. DOI: https//doi.org/10.18421/ IJQR11.01-02.

4. Functioning principles of the internal quality assurance system of educational services / G.A. Oborsky, G.M. Goloborodko, L.M. Perperi et al. Odes 'kyi Politechnichnyi Universytet. Pratsi. 2016. Issue 3 (50). P. 70-73. DOI: //doi.org/10.15276/opu.3.50.2016.12.

5. Шичков Н.А. Выбор методов измерения процессов системы менеджмента качества. Meтоды менеджмента качества. 2005. № 2. С. 14-17.

6. Тріщ Г.М. Система залежностей для оцінювання процесів систем управління якістю підприємств. Восточно-Европейский журнал передовых технологий. 2013. Т. 4, № 3 (64). C. 60-63. URL: http://journals.uran.ua/eejet/article/view/16283/13802.

7. Розроблення кваліметричних підходів до процесів системи управління якістю підприємств згідно міжнародних стандартів ISO серії 9000. Р.М. Тріщ, О.А. Горбенко, Н.А. Доценко та ін. Восточно-Европейский журнал передовых технологий. 2016. Т. 4, № 3 (82). C. 18-24. URL: http://journals.uran.ua/eejet/article/view/75503/80925.

8. Богданов Д.В., Фильчаков В.В. Стандартизация жизненного цикла и качества программных средств. Санкт-Петербург : СПбГУАП, 2000. 210 с.

9. Репин В.В. Бизнес-процессы. Моделирование, внедрение, управление. Москва : Манн, Иванов и Фербер, 2013. 512 c.

10. Перпері Л.М., Оборський Г.О., Голобородько Г.М. Багаторівнева модель управління процесом. Вісник НТУ ХПІ, Серія: Нові рішення в сучасних технологіях. 2017. № 32 (1254). С. 74-79. DOI: https//doi.org/10.20998/2413-4295.2017.32.12.

11. CMMI-DEV, V1.3. Improving processes for developing better products and services. 2010. $482 \mathrm{p}$. TECHNICAL REPORT.

\section{References}

1. On Higher Education System. The Law of Ukraine. No. 1556-VII dated July 1, 2014. Date of update: 28.09.2017. zakon2.rada.gov.ua. Retrieved from http://zakon2.rada.gov.ua/laws/show/1556-18.

2. Luís Fonseca, José Pedro Domingues. (2017). ISO 9001:2015 edition - management, quality and value. International Journal for Quality research, 11, 1, P. 149-158. DOI: https//doi.org/10.18421/IJQR11.01-09.

3. Goutam Kumar Kundu. (2017). Quality in higher education from different perspectives: a literature review. International Journal for Quality research, 11, 1, 17-34. DOI - 10.18421/IJQR11.01-02. DOI: https//doi.org/10.18421/IJQR11.01-02.

4. Oborsky G.A., Goloborodko G.M., Perperi L.M. Guhnin V.P., \& Palennyi Yu.G. (2016). Functioning principles of the internal quality assurance system of educational services. Odes'kyi Politechnichnyi Universytet. Pratsi, 3 (50), 70-73. DOI: //doi.org/10.15276/opu.3.50.2016.12.

5. Shichkov N.A. (2005). Choice of methods for measuring processes of the quality management system. Methods of Quality Management, 2, 14-17.

6. Trisch G. (2013). System of dependencies for assessment of enterprises quality management processes. Eastern-European Journal of Enterprise Technologies, 4, 3 (64), 60-63. Retrieved from: http://journals.uran.ua/eejet/article/view/16283/13802.

7. Trisch R., Gorbenko E., Dotsenko N., Kim N., \& Kiporenko A. (2016). Development of qualimetric approaches to the processes of quality management system at enterprises according to international standards of the ISO 9000 series. Eastern-European Journal of Enterprise Technologies, 4, 3 (82), 1824. Retrieved from: http://journals.uran.ua/eejet/article/view/75503/80925.

8. Bogdanov D.V., \& Filchakov S.P. (2000). Standardization of software life cycle and quality. St. Petersburg: SPbGUAP. 
9. Repin V.V. (2013). Business processes. Modeling, implementation, management. Moscow: Mann, Ivanov and Ferber.

10. Perperi L.M., Oborskiy G.O., Goloborod'ko G.M. (2017). Multilevel model of process management. News of NTU KhPI, Series: New solutions in everyday technologies, 32, 1254, 74-79. DOI: https//doi.org/10.20998/2413-4295.2017.32.12.

11. CMMI-DEV, V1.3. Improving processes for developing better products and services. (2010). TECHNICAL REPORT.

Перпері Людмила Михайлівна; Perperi Liudmyla, ORCID: https://orcid.org/0000-0002-6840-0241

Оборський Геннадій Олександрович; Oborskyi Hennadii, ORCID: https://orcid.org/0000-0002-5682-4768

Голобородько Ганна Михайлівна; Goloborodko Ganna, ORCID: https://orcid.org/0000-0002-2836-7221

Паленний Юрій Григорович; Palennyy Yuriy, ORCID: https://orcid.org/0000-0002-3181-8476 